\title{
HYPOTHYROIDISM FOLLOWING STRUMA OVARII TUMOR RESECTION: A CASE REPORT
}

\author{
Jesus Paula Carvalho, Filomena Marino Carvalho, Flávia Fairbanks Lima \\ de Oliveira and Rosalinda Yossie Asato de Camargo
}

RHCFAP/3080

CARVALHO JP et al. - Hypothyroidism following struma ovarii tumor resection: a case report. Rev. Hosp. Clín Fac. Med. S. Paulo 57(3): 2002.

Struma ovarii is an infrequent ovarian tumor, and there are only few reports with detailed data of thyroid function. In several cases, malignant struma ovarii have been shown to produce hyperthyroidism, but there is no reported case of hypothyroidism following struma ovarii tumor resection.

A 62-year-old white woman underwent right ovary resection that had a pathologic diagnosis of struma ovarii. After 6 days, she developed weakness, myalgia, somnolence, nausea, and arterial hypotension. Laboratory tests showed a high level of thyroid-stimulating hormone (TSH) and a decreased level thyroxin. Thyroxin replacement therapy was initiated, and the patient became completely asymptomatic.

This is the first reported case of a previously asymptomatic woman who developed a definite clinical hypothyroidism after resection of a struma ovarii tumor.

\section{DESCRIPTORS: Ovarian neoplasms. Struma ovarii. Hypothyroidism.}

Struma ovarii is an infrequent ovarian tumor composed entirely or predominantly of thyroid tissue. It is of germ cell origin and accounts for about $2 \%$ of all ovarian germ cell tumors ${ }^{1}$. Struma ovarii are malignant in 5\% to $10 \%$ of the cases, and only $40 \%$ disseminate to extra-ovarian sites. Most of these tumors are asymptomatic, being diagnosed unexpectedly after surgery indicated for a pelvic mass is completed $^{2}$. It is also difficult to distinguish between struma ovarii and dermoid cysts on the basis of their sonographic appearance ${ }^{3}$.

Because of the rarity of the tumor, only a few reports with detailed data on thyroid function of the patient have been published.

In several cases, malignant struma ovarii have been shown to produce hyperthyroidism ${ }^{4}$, but there is no re- ported case of acute hypothyroidism following struma ovarii tumor resection.

\section{CASE REPORT}

A 62-year-old white woman was admitted on August 8, 2000 because of an asymptomatic pelvic mass detected on routine pelvic examination. Ultrasound revealed a normal uterus and a complex ovarian tumor. The contralateral ovary was normal. The computed tomographic scan revealed a right ovarian mass measuring $6 \mathrm{~cm}$ in its largest

From the Departments of Pathology and Gynecology, and Thyroid Unit, Division of Endocrinology, Hospital das Clínicas, Faculty of Medicine, University of São Paulo. diameter (Fig. 1).

Two weeks later, the patient underwent laparotomy and right ovary resection. The ovary was a multilocular cyst measuring $6.5 \mathrm{~cm}$ and containing brown gelatinous fluid. The frozen section examination revealed mature thyroid tis-

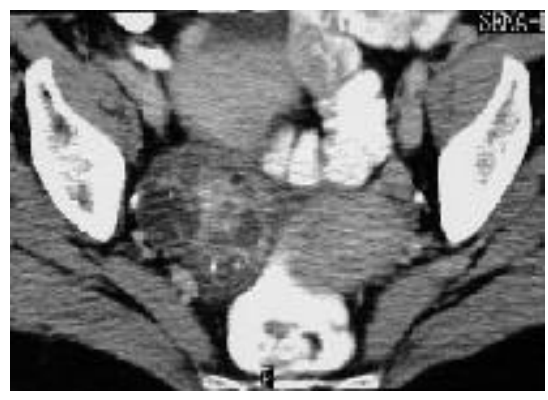

Figure 1 - Computed tomographic scan. Complex right ovarian mass measuring $6 \mathrm{~cm}$ in its largest diameter. 


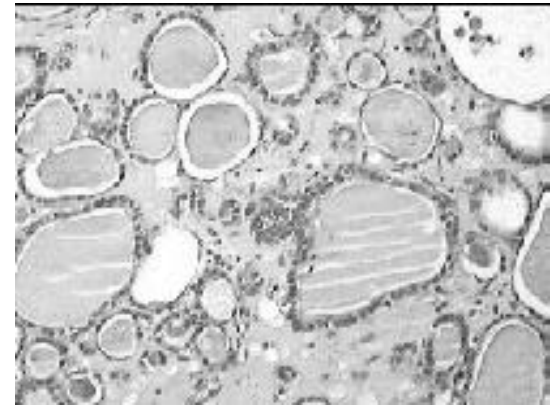

Figure 2 - Thyroid tissue with follicles of various sizes, lined by flat-to-cuboidal cells (hematoxilin-eosin - 100x).

sue, confirmed later by the definitive paraffin examination. The histological examination showed a neoplasia composed of follicles of various sizes, sometimes dilated, distributed in fibrous septa. The follicles contained colloid with scalloped edges and were lined by cuboidal epithelial cells without atypias or mitosis (Fig. 2). Epithelial cells were positive for thyroglobulin as revealed by immunohistochemistry. There was no positivity for thyroid stimulating hormone (TSH). The final histological diagnosis was struma ovarii, and the aspects were similar to nodular hyperplasia of the thyroid gland. The patient recovered well in the immediate postoperative period.

Six days postoperatively, the patient returned to the hospital complaining of weakness, myalgia, somnolence, nausea, and presenting arterial hypotension.

Because of the autonomous ovarian production of thyroid hormone, an acute hypothyroidism after surgical resection was suspected. Laboratory data showed a TSH level of $28 \mathrm{mUI} / \mathrm{mL}$ (normal: 0.5 $4.2 \mathrm{mUI} / \mathrm{mL}$ ), $\mathrm{T} 3$ of $45 \mathrm{ng} / \mathrm{dL}$ (normal: 60 $180 \mathrm{ng} / \mathrm{dL}$ ), T4 of $4.6 \mathrm{ng} / \mathrm{dL}$ (normal: $4.5-$ $12.0 \mathrm{ng} / \mathrm{dL}$ ), free T4 of $0.5 \mathrm{ng} / \mathrm{dL}$ (normal: $0.6-1.54 \mathrm{ng} / \mathrm{dL}$ ), characteristics of a primary hypothyroidism.

The ultrasound examination revealed a hypoechoic and heterogeneous thyroid gland with very reduced volume, suggestive of Hashimoto's thyroiditis.

Thyroxin replacement therapy was initiated at 50 milligrams per day. All symptoms except somnolence disappeared within a week. Then thyroxine was delivered at a higher dosage (75 $\mathrm{mg} /$ day), and the patient became completely asymptomatic.

\section{DISCUSSION}

Ovarian tumors may cause ascite, pain, abnormal bleeding, torsion, intestinal obstruction, virilization, and death, but there is no report of a vital function maintained by an ovarian neoplasm. Struma ovarii is a monodermal teratoma of the ovaries that contains a large amount of thyroid tissue. It is a very uncommon neoplasm, and its diagnosis is almost always done incidentally after an ovarian mass has been removed.

The ultrasound features of struma ovarii are also nonspecific, but a heterogeneous, predominantly solid mass may be seen. Other ovarian teratomas that include mature cystic teratomas (dermoid cysts), immature teratomas, and monodermal teratomas (eg, struma ovarii, carcinoid tumors, and neural tumors) may show the same features ${ }^{5}$. Struma ovarii occurs more frequently in premenopausal women, and the mean lesion diameter rarely exceeds 6 cm diameter ${ }^{3}$.

Struma ovarii tumors are typically filled with clear to green-brown fluid. Microscopic examination shows follicles and cysts of various sizes separated by fibrous septa. The cysts are usually lined by nonspecific-appearing, flat-to-cuboidal epithelial cells. Scalloping of the colloid suggests hormonal activity of the neoplastic cells. The paucity of thyroid follicles in many areas and the nonspecific appearance of the epithelial cells lining the cysts often cause the diagnosis of struma ovarii to be overlooked ${ }^{6}$.

Struma ovarii may cause hyperthyroidism, and differential diagnoses should include consideration of ectopic causes of hyperthyroidism, such as factitious thyroid hormone ingestion, and rarely, large deposits of functioning thyroid cancer metastases.

Several other authors have reported hyperthyroidism caused by struma ovarii $^{7}$. Lazarus et al. ${ }^{8}$ described a patient with struma ovarii and hyperthyroidism whose diagnosis was made by radioiodine profile scanning, and an ovarian tumor was removed. The patient was treated for Graves' hyperthyroidism at age 22, and 20 years later she became thyrotoxic. Grandet \& Remi ${ }^{9}$ reported a case of hyperthyroidism after total thyroidectomy. A whole body scan with iodine-131 confirmed astruma ovarii that was bilateral, which occurs in $5 \%$ to $10 \%$ of patients with this condition.

Malignant transformation of struma ovarii is a very rare condition, with clinically evident metastatic disease reported in approximately 20 cases in the literature. Takeuchi et al. ${ }^{10}$ described 2 cases of malignant struma ovarii that demonstrated widespread peritoneal metastases. One of them recurred 2 years later in the contralateral ovary and omentum, while the primary tumor previously was pure struma ovarii with no evidence of metastasis. Patients with malignant struma ovarii who had elevated thyroglobulin levels at the time of surgery can be observed for recurrence on the basis of progressive thyroglobulin level elevation.

We have reported the first case of a previously asymptomatic woman developing a definite clinical hypothyroidism after resection of a struma ovarii tumor. In spite of the fact that she developed a chronic autoimmune thyroiditis that was confirmed by laboratory tests and ultrasonographic characteristics, she was asymptomatic; the ovarian tumor probably maintained normal thyroid function. Chronic autoimmune thyroiditis is a common finding in women after the fourth decade of life. Although the struma ovarii is a very rare tumor, the association with hypothyroidism can occur and requires an adequate replacement of thyroid hormone after surgery. 
CARVALHO JP e col. - Hipotireoidismo após ressecção de tumor struma ovarii: relato de caso. Rev. Hosp.

Clín. Fac. Med. S. Paulo 57(3): 2002.

Struma ovarii é um tumor infreqüente com poucos relatos de casos abordando detalhadamente a função tireoidiana. Na maioria dos casos têm sido demonstrado que o struma ovarii produz hipertireoidismo, entretando não existe relatos de desenvolvimento de hipotireoidismo após a retirada deste tumor.

Uma mulher branca de 62 anos foi submetida a oforectomia direita com diagnóstico anatomopatológico de struma ovarii. Após seis dias da cirurgia, a paciente desenvolveu fraqueza, mialgia, sonolência, náusea e hipotensão arterial. Exames laboratoriais demonstraram níveis elevados de hormônio tireo-estimulante (TSH) e baixos de T3 e T4. Foi iniciado terapia de reposição de tiroxina e a paciente recuperou seus parâmetros clínicos e laboratoriais.

Não existe, até o momento, relato de hipotireoidismo seguindo a exerese de struma ovarii. Este é o primeiro caso de uma mulher com função tireoidiana prévia normal que desenvolveu hipotireoidismo clínico após a ressecção de um tumor ovariano struma ovarii.

DESCRITORES: Neoplasia ovariana. Struma ovarii. Hipotireoidismo.

\section{REFERENCES}

1.ROTMAN-PIKIELNY P, REYNOLDS JC, BARKER WC et al. Recombinant human thyrotropin for the diagnosis and treatment of a highly functional metastatic struma ovarii. J Clin Endocrinol Metab 2000; 85:237-244.

2.BERGHELLA V, NGADIMAN S, ROSENBERG H et al. - Malignant struma ovarii. Gynecol Obstet Invest 1997; 43:58-72.

3.ZALEL Y, SEIDMAN DS, OREN M et al. - Sonographic and clinical characteristics of struma ovarii. J Ultrasound Med 2000; 19:857-61

4.KANO H, INOUE M, NISHINO T et al. - Malignantstruma ovarii with Graves' disease. Gynecol Oncol 2000; 79:508-10.

5.OUTWATER EK, SIEGELMAN ES \& HUNT JL - Ovarian teratomas: tumor types and imaging characteristics. Radiographics 2001; 21:475-90.
6.SZYFELBEIN WM, YOUNG RH \& SCULLY RE - Cystic struma ovarii: a frequently unrecognized Am J Surg Pathol 1994; 18:785-8.

7.DUNZENDORFER T, DELAS MORENAS A, KALIR T et al. Struma ovarii and hyperthyroidism. Thyroid 1999; 9:499502.

8.LAZARUS JH, RICHARDS AR, MACPHERSON MJ et al. - Struma ovarii: a case report. Clin Endocrinol 1987; 27:715-20.

9.GRANDET PJ \& REMI MH - Struma ovarii with hyperthyroidism. Clin Nucl Med 2000; 25:763-5.

10.TAKEUCHI K, MURATA K \& FUJITA I - "Malignant struma ovarii" with peritoneal metastasis: report of two cases. Eur J Gynaecol Oncol 2000; 21:260-1.

Received for publication on August 13, 2002. 